Portland State University

PDXScholar

6-16-2021

\title{
The Band Chervona: Russian Musical Traditions in the Portland Diaspora
}

Zoe Landi Fontana

Portland State University

Follow this and additional works at: https://pdxscholar.library.pdx.edu/honorstheses

Part of the Other Music Commons, and the Slavic Languages and Societies Commons Let us know how access to this document benefits you.

\section{Recommended Citation}

Landi Fontana, Zoe, "The Band Chervona: Russian Musical Traditions in the Portland Diaspora" (2021). University Honors Theses. Paper 1110.

https://doi.org/10.15760/honors.1137

This Thesis is brought to you for free and open access. It has been accepted for inclusion in University Honors Theses by an authorized administrator of PDXScholar. Please contact us if we can make this document more accessible: pdxscholar@pdx.edu. 
The band Chervona: Russian Musical Traditions in the Portland Diaspora

\author{
by \\ Zoe Landi Fontana
}

An undergraduate honors thesis submitted in partial fulfillment of the requirements for the degree of

Bachelor of Arts

in

University Honors

and

Russian

Thesis Adviser

Dr. Cassio de Oliveira

Portland State University 


\section{Introduction}

A 2014 report by the Coalition of Communities of Color, in collaboration with Portland State University, was published on the rapidly growing Slavic community in Multnomah County, Oregon. Despite the fact that this demographic is the largest refugee-based community in Oregon, members of it often go invisible because of the lack of data on their experiences in welfare, justice, health, and school systems. The majority of Portland's Slavic community arrived between 1990 and 2000, after the fall of the Soviet Union (Curry-Stevens, 2014).

One of these immigrants was Andre Temkin, who arrived in the late 1990s, coinciding with this largest wave. Within a few years of his arrival, he was playing in a Russian-American fusion rock band. By the mid 2000s, Temkin was leading the group Chervona, an EasternEuropean inspired street band. Chervona gained popularity in the Portland community, as is evidenced in local magazines and newspapers. The success of Chervona is a manifestation of one way that a minority community gained visibility through its art. Considering that the group draws on Eastern-European musical traditions, its prominence on the Portland music scene simultaneously increases the visibility of the rest of the Slavic community as well.

Through an analysis of published media, including online newspapers, recorded concerts, news clips, and blog sites, this paper will explore the ways in which Temkin's evolution from Starbugs to Chervona, focusing on the bands' repertoire, is a reflection and continuation of Russian musical legacy that, as a result of its existence in diaspora, also serves as a musical facilitation of multicultural communication.

In order to reveal the various ways in which Chervona expresses qualities of Russian musical legacy, the paper is split into a few sections - the history and development of Chervona, 
a discussion of the meaning of "Russian", an analysis of Chervona's discography, ending with a few thoughts on the musician as an individual.

The overview of Chervona and explanation of its two predecessors provides a holistic understanding of the band's situation in Portland. Knowing what did or did not work for Andrei Temkin, a Russian immigrant joining Portland's music scene, evaluates the receptivity of the Portland audience and further underlines the surprising fact that even non-Russian speakers become fans of Chervona. Later, discussing the meaning of "Russian" draws connections between Temkin, his band, and the home country from which he and his musical influences hail. This paper's definition of “Russian”, in conjunction with Temkin's ethnic background, provides the context to show that Chervona is truly Russian. The next section is an analysis of Chervona's discography. The table provided lists each song with its language, the roots of the melody, and includes short descriptions on the content of the lyrics. Listening to each song in this way facilitated the identification of characteristics or melodic roots that make Chervona's music Russian. The discography analysis is accompanied by a section detailing Shanghai's Russian diaspora of the 1930s and 40s, as a result of the numerous musical parallels between Portland's Russian diaspora and 1930s Shanghai's. Before concluding, two of Chervona's newest songs are analyzed separately to see if the band continues to draw from its Russian roots up into the past year. The paper concludes with a discussion on the implications of its findings, for the community and for the musician as an individual as well. 


\section{An overview of the group Chervona}

The group Chervona was founded in 2006. As stated on their website, Chervona contains a mix of Romani, Russian, Ukrainian, Klezmer, and Balkan music. As for a genre, Chervona draws from the following — Romani, klezmer, Dixieland, polka, swim, ska, punk. The atmosphere they evoke is that of an Eastern European carnival. Since its founding, membership has changed a few times, but the current roster is as follows: Andre Temkin, Roman Tchamsky, Andrew Alikhanov, Thomas de Almeida, Anton Van Oosbree, Adam Schneider, and Olimpia Trusty. It is a Russian band enriched by having Armenian, Jewish, Italian, Brazilian, German, Argentinian, and Kazakhstan influences. Of the members, three hail from the former USSR. Chervona is the result of over a decade of music making and networking to find an arrangement that expresses the roots of the group, and also caters to the local non-Russian community.

Chervona draws from a diverse background of musical genres and cultures, as can be heard in their performances, distributed online. This is indicative of Chervona's development into a group that can attract a wide audience in Portland, while decisively presenting itself as "other".

The history of the band reveals how Chervona, gaining recognition and popularity,

became the most successful out of Temkin's bands. This recognition is not only of the band itself, but also of the diaspora community that Temkin belongs to.

\section{The Evolution from Starbugs to Mirumir to Chervona; a short history}

Using Google as the primary search engine for finding published material on Chervona, Mirumir, and Starbugs, the resulting articles had a few key similarities: they were published from 
1999 to around 2015, location of publication remained local to the Portland metropolitan area, and the articles tended to focus on the fact that these musicians were immigrants. The focus on the musician's foreign origins is written in a friendly and curious way, which contributes to the way the rest of the local community may view them as well.

Andre Temkin, a native of St. Petersburg, had always existed within music, but did not receive formal musical training. His first band Starbugs was created in his first house in Portland, Oregon. This rock group, called Starbugs and born within only a couple years of Temkin's arrival in Portland, received coverage in local media, immediately placing Temkin, lead vocalist and guitarist, and Alexey Yevstigneyev, drummer, within the music scene.

Starbugs was mentioned in a 2001 column for "Two Louies Magazine", a local music magazine. In telling the band's story, the author, Robin Rosemond writes “it's definitely a bit foreign, but that's what makes it good" and "Andre and Alexey both moved from Russia to America in 1995 with the dream of someday starting a rock and roll band. For [Andre] and Alexey, the American dream still has great meaning and continues to bring people to our shores for artistic freedom and a chance to make some dough." (Rosemond, 2001) She compares Andrei Temkin and Alexey Yevstigneyev to a Ukrainian-American figure skater who won Olympic gold and made herself a comfortable life in the US. This depiction of Temkin and Yevstigneyev is highly idealistic in how it speaks of the United States. The American Dream is not attained by all, considering the possible linguistic, cultural, and religious barriers that immigrants face. Regardless, Rosemond has portrayed these two musicians as hopeful artists and individuals who bring value, in the form of music, to their new home. 
A similar article was published in Portland Mercury on June 7, 2007 titled "Our Town Could be Your Life" with a subheading of "Immigrants" author Cary Clarke explores how and why Andrei Temkin, an immigrant from Russia, and Eric John Kaiser, from France, moved to Portland. Temkin, like Kaiser, who came to Portland following both good reviews of the city and friends, had stumbled upon an American magazine about Portland that touted the city as the best in America. According to Clarke, Portland seemed to be becoming less provincial, and more open to foreign influences - at least in the music sphere. Again, this article both highlights Temkin's foreign origins and promotes the musical influences that he brings with him, a positive depiction. (Clarke, 2007)

In presenting Temkin and his bands with a strong emphasis on that they are immigrants, an expectation is set that what listeners will hear will be distinctly different from what they might expect to hear from a local musician born and raised in Portland, with family residing in the United States for at least a couple of generations. This expectation makes Temkin's music come across as more Russian, or foreign, from the start.

A Willamette Weekly article explores how the foundations on which Andre Temkin and Alexey Yevstigneyev built their rock band Starbugs, a predecessor to Chervona, came from a legacy of underground political rock in the USSR. Titled "From Russia with Shove: The Starbugs combine Russian passion and Yankee brawn into nuclear-powered rock", the article was written at a time when the band had performed just a handful of times at party gigs, and was fresh to the Portland music scene. The author, Zach Dundas, visited the group in their basement on Ankeny Street, where the Starbugs, consisting of two Russians and two Americans, jammed. 
In this mix, described as "Superpower cooperation that works", Dundas observes the differences between American and Soviet rock (Dundas, 2000).

The Perestroika era of the Soviet Union gave birth to such rock legends as Kino. There was an abundance of music in this era, yet rock was labeled taboo and depraved. Rock served the purpose of putting to music the feelings of a generation growing up in an unraveling country. Viktor Tsoi, of Kino, wrote simple songs that reached everyone. He sang about wanting change in the country, the hopelessness young people would feel, and the desire for peace and freedom. Rock in the USSR, Temkin says in the interview "[was] a form of social protest. Music wasn't the first thing. The lyrics are the biggest deal." (Dundas, 2000) Andrei brought this legacy with him when he emigrated to Portland when he created Starbugs.

After a few years, Starbugs became defunct and a new band stood at the forefront of Temkin's musical career in Portland. It was named Mirumir. The name Mirumir is worth discussing as the phrase comes directly from Soviet history. The motto means "peace to the world" and was used widely after the February Revolution. Even the poet Mayakovsky ended a poem about war with the phrase. (Dushenko, 2005) Using such a deeply nuanced Russian phrase to name their band comes from their Russian heritage and a desire to continue promoting peace among nations, but in a new setting and under their own control in the United States.

Chervona evolved out of Mirumir and became the most successful of Temkin's groups for a few reasons, one being that it was easier to find an audience while playing on the street, than to find venues for performing rock. They began to play on the streets with acoustic instruments, at places like the Alberta Street Festival. They chose to play chansons, Soviet era tunes, and Romani songs, popular within Russia for over a century. Surprisingly, these tunes attracted 
Portlanders at street festivals and even got them dancing, despite them not understanding the language.

Chervona quickly picked up gigs as a party band and also began to throw a few regular events of their own. An observation of interest is the development of Temkin's bands in the United States. In order of age, the bands are Starbugs, Mirumir, then Chervona. Looking at this progression, and knowing the relative repertoire of each group, it is noticeable that Temkin's bands did not start out with a strong Russian focus. Over time, the band evolved and began to take more influences from song types popular in Russia, which directly coincided with its growing popularity. Chervona is a group that strongly identifies with the members' shared history of growing up in the USSR. As the band grew, they began to throw Russian themed parties. Each of these parties were attended by people of all backgrounds, not exclusively those with ties to Russia or Eastern-Europe. The organizers were able to share both their history and their music with people who might not otherwise be able to experience it in such a dynamic way. One benefit of this is the ability for attendees to walk away with a completely different take on Russian, and Soviet, culture. Revolution Party, Russian Halloween, and Stariy Noviy God - the Old New Year - were held at various Portland venues. Revolution Party was a party to poke fun at the October Revolution, a holiday that was seriously observed during the Soviet era. Russian Halloween in 2018 had a "Odessa speak-easy" theme, that harkened back to the beginning of the Russian Revolution, and gave attendees the chance to dress up in the garb of that era.

Chervona's biggest event annually is the Old Russian New Year. Russia followed the Julian calendar until after the revolution. According to this calendar, the new year lands a couple of weeks after the New Year per the Gregorian calendar. For Chervona, its fans, and anyone 
looking for a reason to celebrate, it is another reason to party. In a 2014 news spotlight on "Good Day Oregon", Andre and Alma Temkin appear dressed for Chervona's annual Russian Old New Year party. Andre and Alma promote the event set to take place at the Starlight Theater and educate viewers on some Russian holiday traditions. They presented the stories of Ded Moroz and Snegurochka, then Andrei Temkin explained how to properly drink vodka with a few choices of zakuski, small plates of food traditionally served alongside alcohol. Chervona ended the segment with an excerpt of their rendition of Ochi Chorniye, a popular Romani song. Chervona's annual Russian Old New Year Party invites those unfamiliar with Russian culture to experience a friendly night of music and food, with an emphasis on Russian music and food. The Russian Old New Year Party gives the members of Chervona the opportunity to put their cultural background on display in a way that reflects who they are as artists, as well as bring visibility to their community. Chervona is still alive and well, producing music at a slower rate during the pandemic, but nonetheless persevering.

\section{What Makes Chervona Russian?}

A style of music is not exclusive to the region in which it originated. The same style of music can be performed in other environments. This movement to a new setting, however, allows for it to be influenced anew. This brings Chervona into the realm of hybridity. Hybridity “...does not imply the existence of a 'pure' essential item culture in contrast to a hybrid one. It simply seeks to emphasize the synthetic, unfinished, and potentially changing character of cultural constructions, particularly from the diasporic ones" (González, 2019, p.177) This excerpt comes 
from a paper on the Italian diaspora in Argentina. The notion of hybridity expressed is also pertinent to Chervona's experience in the United States.

The traditional songs that Temkin grew up hearing in the USSR take on new meanings when played in the United States. Chervona presents the songs with its own lively twist. The members of Chervona do not expect their entire audience to understand the lyrics nor the historical backgrounds of the songs they choose to cover. What Chervona does is to understand the international appeal of chansons, Romani romances, Soviet songs, and traditional music and to use them to bridge the gap between those who are from a Russian background, and those who are not. Chervona creates covers and original songs with polka rhythms, strong klezmer style violin and clarinet lines, and accordion, but will start their Russian language songs with a little musical description in English on what the gist of the song is. This is hybridity, in that it does not require Chervona to abandon the songs of their childhood and country fearing that the Portland audience will find them too foreign, but instead they choose to adapt them to make them understandable to this new audience, all the while maintaining their musical and linguistic integrity.

The definition of "Russian" is not definitive. To allow for discussions of music in diaspora, "Russian" must encompass more than a place of origin. Taking the 2014 report by the Coalition of Communities of Color's definition of "Slavic" as anyone coming from areas within the former Soviet Union is problematic because it renders invisible the diversity of nationalities contained within the former USSR (Curry-Stevens, 2014).

In discussions of multiculturalism, cultures are not distinct. They are constantly influencing one another through the forces of imperialism, migration, war, and trade. (Song, 
2020). The Russian Empire, Soviet Union, and even the current Russian Federation all contained within its borders many different ethnic groups through the processes of imperialism and forcing ideologies. The sheer size of the country also enables it to encompass many different ethnicities. It should be noted that because of the imperial history of Russia and the USSR, many characteristics of "Russian" music are contributions from various cultures within the vast country's borders over centuries. The Russian Federation contains at least 150 different identified ethnicities, and the Soviet Union controlled an even greater variety. The USSR, like modern Russia, spanned two continents and included ethnic groups including peoples of the Caucasus. to Central Asians, the groups of the Far East in Siberia, Romani people, and all the Abrahamic religions. All of this had an effect on the music

Chervona labels itself as having Romani, klezmer, Dixieland, polka, swing, ska, punk, Ukrainian, Russian, and Balkan traditions in its music. It does not call itself a Russian group, but it could be considered one, taking into account the previous history of Russia through imperial, Soviet, and modern times. The members of Chervona decided to form a group based on EasternEuropean traditions. Band members come from different backgrounds - three from the former USSR, and the rest from the United States. The influences from the territories of the former USSR contribute to how Chervona creates music in Portland.

Defining Chervona brings up questions of diaspora. For the three musicians hailing from the former USSR, the experience of creating music within the band involves creating the music from their homeland in diaspora. Diaspora is “....a denotative label for the dispersed people removed from a common territorial origin". (González, 2019, p.175) The territorial origin in question here is the former USSR. Diasporic cultures, established through displacement, go 
through a process of incorporating themselves into the new culture while simultaneously maintaining their differences.

In deciding to maintain a strong sense of Russian and Soviet identity, the emigres of the group carefully navigate creating a diasporic identity. They have done this by creating songs in both English and Russian. Their English songs use the same klezmer and polka styles as the Russian ones, and their Russian songs include English parts to explain the song's narrative or to help the audience sing along. Judging by the aforementioned articles in the previous section and Chervona's extensive performances throughout the Pacific Northwest, their approach to playing Russian music in the Portland scene has been successful. Without having to reject any facets of themselves, the group members can both maintain their differences, exemplified through the music they create, and incorporate themselves into the local music scene.

\section{Analyzing discography}

The following is a collection of Chervona's repertoire and discussion based on the songs' lyrics, arrangements, and harmonies. This collection was found online through the band's website, YouTube channel, Facebook page, and Soundcloud. The analysis will delve further into the question of what makes Chervona Russian by listening to the group's discography. The listener should consider that the band indeed has Russian roots, but the fact remains that its birthplace was Portland. This highlights Chervona's hybridity of being Russian and American.

The most complete collection of recordings was found on SoundCloud. The recordings, some full songs, others consisting of snippets, will be categorized in the table below by the following criteria: title, language, genre and instrumentation, then a general description. 


\begin{tabular}{|c|c|c|c|}
\hline Title & Language & Roots & Description and Notes \\
\hline $\begin{array}{l}\text { Ochi Chernye (Dark } \\
\text { Eyes) }\end{array}$ & English to Russian & Romani romance & $\begin{array}{l}\text { The song opens up in } \\
\text { English with a } \\
\text { description of "Ochi } \\
\text { Chernye" for those } \\
\text { who don't know its } \\
\text { roots }\end{array}$ \\
\hline Reality Show & Russian to English & polka & $\begin{array}{l}\text { A carnival inspired } \\
\text { original song, } \\
\text { reminiscent of a ring } \\
\text { leader opening a show }\end{array}$ \\
\hline Chervona Wine & English with Spanish & $\begin{array}{l}\text { polka bass with a } \\
\text { swing melody }\end{array}$ & $\begin{array}{l}\text { The song is a little bit } \\
\text { about anti-war and a } \\
\text { lot about the wish for } \\
\text { everyone to be } \\
\text { peaceful and drink } \\
\text { "chervona" (red) wine }\end{array}$ \\
\hline Serdze (Heart) & Russian & $\begin{array}{l}\text { tango to slow polka, } \\
\text { prominent trumpet } \\
\text { solo }\end{array}$ & $\begin{array}{l}\text { About girls and } \\
\text { struggles in love }\end{array}$ \\
\hline Rasputin & English & $\begin{array}{l}\text { klezmer, prominent } \\
\text { accordion }\end{array}$ & $\begin{array}{l}\text { Bonney-M's } \\
\text { "Rasputin", about the } \\
\text { corrupt and violent } \\
\text { Russian mystic }\end{array}$ \\
\hline Romale (Roma) & Russian to English & $\begin{array}{l}\text { polka, circus theme } \\
\text { played by trumpet }\end{array}$ & $\begin{array}{l}\text { A song welcoming the } \\
\text { audience to their } \\
\text { show. "Romale", the } \\
\text { Romani word for a } \\
\text { Roma person }\end{array}$ \\
\hline
\end{tabular}




\begin{tabular}{|c|c|c|c|}
\hline 7 String & English & polka & $\begin{array}{l}\text { Tells the story of a } \\
\text { misfortunate man, } \\
\text { who also plays the } 7- \\
\text { string guitar. The } 7- \\
\text { string guitar was } \\
\text { developed and } \\
\text { popularized in Russia } \\
\text { near the end of the } \\
1700 \text { s and early } \\
1800 \text { s. }\end{array}$ \\
\hline Gypsy & Russian & $\begin{array}{l}\text { Romani rhythms, } \\
\text { Romani- inspired } \\
\text { original song. } \\
\text { Prominent violin and } \\
\text { clarinet }\end{array}$ & $\begin{array}{l}\text { About a man whose } \\
\text { soul is sad because of } \\
\text { a girl }\end{array}$ \\
\hline Girlfriends Are Pain & English & polka & $\begin{array}{l}\text { A comedic song about } \\
\text { a man having } \\
\text { problems with his } \\
\text { girlfriend, then the } \\
\text { girlfriend's side of the } \\
\text { story is told }\end{array}$ \\
\hline $\begin{array}{l}\text { Kakoe Nebo (What a } \\
\text { Sky) }\end{array}$ & Russian & $\begin{array}{l}\text { carnival vibes, } \\
\text { clownish, brass slides }\end{array}$ & $\begin{array}{l}\text { A song about happy } \\
\text { days and blue skies }\end{array}$ \\
\hline Hammony & $\begin{array}{l}\text { English with some } \\
\text { shouted Russian } \\
\text { phrases }\end{array}$ & sailor song & $\begin{array}{l}\text { Inspired by the } \\
\text { Muslim Call to Prayer } \\
\text { and images from te } \\
\text { Soviet film "The } \\
\text { White Sun of the } \\
\text { Desert", Also a sailor } \\
\text { song about going } \\
\text { home drunk with a } \\
\text { companion }\end{array}$ \\
\hline Blondinki & Russian & Dixieland jazz & $\begin{array}{l}\text { A song about blondes } \\
\text { that the singer likes }\end{array}$ \\
\hline
\end{tabular}




\begin{tabular}{|c|c|c|c|}
\hline Behind the Bars & Russian & $\begin{array}{l}\text { A Romani inspired } \\
\text { song from the Soviet } \\
\text { film "The Elusive } \\
\text { Avengers" with added } \\
\text { Klezmer influences, } \\
\text { heard in the exposed } \\
\text { violin line }\end{array}$ & $\begin{array}{l}\text { A Romani romance } \\
\text { about a young couple } \\
\text { sneaking around }\end{array}$ \\
\hline Valenki & Russian & $\begin{array}{l}\text { Russian folk song, the } \\
\text { original is } \\
\text { accompanied by just } \\
\text { accordion }\end{array}$ & $\begin{array}{l}\text { A song about } \\
\text { traditional felt boots } \\
\text { and being in love } \\
\text { despite freezing } \\
\text { weather }\end{array}$ \\
\hline $\begin{array}{l}\text { Blue Ball } \\
\text { Shar goluboy }\end{array}$ & Russian & $\begin{array}{l}\text { Russian romance } \\
\text { from the } 19 \text { th century, } \\
\text { with added carnival } \\
\text { motifs on accordion }\end{array}$ & $\begin{array}{l}\text { Sings about a blue } \\
\text { balloon and being in } \\
\text { love with a countess }\end{array}$ \\
\hline $\begin{array}{l}\text { Russian Jail Song } \\
\text { Postoy parovoz }\end{array}$ & Russian & $\begin{array}{l}\text { A well-known song } \\
\text { from Leonid Gaidai's } \\
\text { Soviet comedy } \\
\text { "Operation bI and } \\
\text { other adventures of } \\
\text { Shurik" }\end{array}$ & $\begin{array}{l}\text { A prisoner waits for a } \\
\text { steam engine and } \\
\text { reflects on his fate }\end{array}$ \\
\hline $\begin{array}{l}\text { These are the Days } \\
\text { Dorogoy dlinoyu }\end{array}$ & English & $\begin{array}{l}\text { Originally a Russian } \\
\text { romance, made } \\
\text { livelier with clarinet } \\
\text { solo }\end{array}$ & $\begin{array}{l}\text { Reminiscing on } \\
\text { bygone youth }\end{array}$ \\
\hline $\begin{array}{l}\text { Three White Horses } \\
\text { Tri byelix konya }\end{array}$ & Russian & Soviet New Year song & $\begin{array}{l}\text { About three white } \\
\text { horses that pull a sled } \\
\text { (troika), representing } \\
\text { the three months of } \\
\text { Winter }\end{array}$ \\
\hline
\end{tabular}

Chervona is a thorough interpreter of Russian popular music. The songs listed above, excluding the originals written by Chervona, are well-known to most Russians and many who grew up in the former USSR. Romani romances, old Russian romances, songs from Soviet films, 
and Russian folk songs were popular genres throughout the last century. Chervona makes these songs accessible to Portland audiences, who might otherwise never be exposed to these genres, by performing them in their own interpretation. The Chervona interpretations do not require that the audience know the lyrics or cultural significance behind a song — what the group relies on is pure enthusiasm and lots of high energy instrumental solos.

Chervona inadvertently draws from its listener a feeling of nostalgia by playing songs in minor keys, even those that are original compositions. The band uses a number of acoustic instruments. The style in which the instruments are played give Chervona its nostalgic folk atmosphere. The violin and clarinet are used for klezmer songs. The violin and guitar are also key to playing Romani romances. The trombones and tuba allow the band to play polka. The accordion is a fundamental instrument for Russian romances and Soviet popular tunes. A song, for example "Ochi Chorniye" features a Romani style violin line. In their next song, the band might play "Valenki", a Russian folk tune, whose primary accompaniment is the accordion, but the violin will still support in the background. Through each piece, the tuba plays a polka bass line, which creates rhythmic continuity between songs. The mix of instruments allows to play various styles, but also maintain a sense of continuity throughout a set of songs.

The evolution from Starbugs into Chervona, and the place that the band holds within the Portland community, bear a close resemblance to the situation in Shanghai in the 1920s to early 1940s. The Russian emigre community of Shanghai came from the upper middle class. They were educated, urban professionals, whose jobs brought them from Western Europe to Siberia or East Asia, ending up in Shanghai after the 1917 Revolution. As a result of the ensuing Civil War, mass emigration occurred from the former Russian Empire to neighboring countries. For those 
who could not afford going to a Western country, or were fleeing the Eastern part of the Russian Empire, China was a more viable option.

The Russian community was musically active in its new home. Unlike the Western expatriates of French, British, or American origin, the economic statuses of the Russian emigres was more diverse, and was primarily middle-class, although Russian elites existed there as well. (Yang et. al, 2020) As a result, a large number of Russians developed the spheres of entertainment and music. Like Chervona's Russian Old New Year Party held annually in various Portland clubs, the Russian emigre community of Shanghai also used this old holiday to put themselves on the local calendar of events. Eventually, the Russian New Year became one of the few major balls held in Shanghai annually.

The annual Russian New Year ball was not accessible for all. The Russian emigres in Shanghai brought with them many of the social structures that had existed in the former Russian Empire. The aristocracy and the families of elite military officers maintained a similar status in Shanghai as in Russia. For those who did not belong to this upper strata, restaurants and clubs were open to ring in the New Year. Notably, the music most often performed, and that garnered attention from beyond the Russian community, was Russian romances, Russian authors songs, and other popular genres. The definition of "Russian" in the Shanghai diaspora was not synonymous with the contemporary definition of Russian ethnicity. The Shanghai diaspora of "Russians" was a heterogeneous group made up of Poles, Finns, Jews, Russians, and other subjects of the former Russian Empire. (Yang et. al, 2020) These similarities speak to the enduring legacy of music and its ability to not only flourish in new environments, but to serve as a means of communication and multicultural integration. 
The significance of the Shanghai Russian community case is exemplified by the parallels it draws to Chervona's existence within Portland. Even the acceptance of a heterogeneous definition of "Russian" in Shanghai bears a resemblance to the complexities in labeling the Russian-speaking diaspora in Portland. Musicians of the Russian Shanghai community found success playing chansons, Romani romances, and Russian author songs, similar to that Chervona has in performing and arranging some of the same songs, with the addition of Soviet tunes, almost 100 years later. Both diaspora communities used music to preserve heritage and to create visibility within their new environments.

\section{Recent Work}

In 2020, Temkin produced two new songs along with music videos. In analyzing them, it is again apparent that the songs pull from Russian and Soviet perceptions, although their styles are markedly different from Chervona's previous recordings."Heavenly Pussycat” or "Nebesnaya koshka” was produced in 2020 and released just in time for New Year 2021. "Heavenly Pussycat" is named for the qualities of the sky at night, there being a "starry milk" (zvesdnoe moloko) and the tails of comets that resemble those of cats.

This song is composed on Russian New Years traditions. The biggest Winter holiday in Russia is New Years, not Christmas. Despite not being a Christmas song, it nonetheless calls on Santa Claus, instead of Ded Moroz, or Russian Grandfather Frost. Both names contain the same number of syllables and similar vowel placement, so deciding to use Santa Claus instead of Ded Moroz could be to make the song more suitable for the United States' holiday traditions. The music video is filmed in a house with holiday decor. There are Santa Clauses, elves, and 
stockings, all associated with Christmas, but on the television is a scene from "The Irony of Fate" a Soviet New Year film synonymous with the holiday. The song has hints of Christmas in it, perhaps an influence of Temkin being in the United States for more than 20 years already, but it is at heart a New Years song wishing hope to everyone and to move on from the difficult 2020 year. The lyrics are conveniently provided in the original Russian and with an English translation in the video's description.

The second song is also sung in Russian, but in a completely different style. It was produced under the group Mirumir. Recorded in December of 2020, Mirumir made a comeback with the song "FREEDOM-LOVE (SVOBODA-LYUBOV')". Sung by Alexey Ryskin (stage name "Krasavchik") and Andre Temkin, this new song was published on the YouTube channel "Volta Dzemka", a Belarusian culture page. The musicians may have chosen to present their support in the form of rock instead of, for example, a "world-music" ensemble that is typical of the group, because of the history of rock and protest in Russia and the former Soviet space. "FREEDOM-LOVE" continues the legacy of Soviet rock, although its style is reminiscent of 90s Russian rock bands like B-2, Spleen, and Zveri, which were less politically charged than Perestroika rock. The lyrics of "FREEDOM-LOVE" describe the protests that occurred in response to corrupt presidential elections in Belarus in 2020.

\section{The Musician is an Individual}

A style of music does not move on its own, and the musicians that do bring new influences from abroad are characterized by much more than a single ethnic identity. What Temkin does as a musician, can be described by "calibration". Calibration, according to scholar 
Ato Queson, is a metaphor for the adjustments a musician makes in a certain place, taking into consideration contrasting discourses. (Ramnarine, 2007) Temkin arrived in Portland and started playing rock in Starbugs. Then, he started a "world-music" group, Mirumir. Eventually, the "world-music" that the band played leaned towards the diversity of Russia. These adjustments are indicative of Temkin, and his bands', experience of calibration. Temkin's music evolved and went in the direction of where they found popularity, which ended up being in arranging and playing Russian-style songs.

It should be remembered that even an artist that presents himself using his ethnicity as part of his public persona is not a monolith of his ethnicity. Andrew Temkin can be considered a Russian musician because Russia is the place of his birth and half of his life. In Russia, however, playing similar music as Chervona, the focus would not be on his nationality. His inspiration does not come exclusively from his Russian background. For Temkin, reggae is essential to his being. Through watching his videos taken in Jamaica, it is obvious that reggae plays a considerable role in the way he approaches music and life. Although it is not a genre normally associated with Russia or Russianness, Temkin cares for it, so it becomes part of who he is inherently as a musician. It follows, then, to view and listen to foreign musicians with a wider lens than merely tokenizing their ethnic backgrounds. Chervona should be listened to and understood as one manifestation of Russian heritage in Portland. It is a band that caters to an audience. Over time, adjustments were made in reaction to the surprising positive feedback the local audience had to Russian songs. 


\section{Conclusion and implications for the field and musicians}

Starbugs, Mirumir, and Chervona have always had a strong basis in Russian culture. If the songs that Starbugs created were not Russian in their style, Temkin and Yevstigneyev imbued meaning into them, having come from and internalized an established tradition of lyric-focused rock. Mirumir was its own version of a multicultural, world music group. Like Gogol Bordello and Manu Chao, with whom Mirumir has performed alongside, Temkin and the other group members created their own mixture of various cultures to which they had connections. Chervona is the most Russian of all, in its repertoire, instrumentation, and presentation, as well as the most successful. The implications for Portland and for musicians is that music can be a tool for communication, as seen in the case of Shanghai's Russian community. Chervona has found a way to use its ethnic heritage to increase visibility and create a positive and dynamic view of what Russian can mean. In doing this, it shows that being a part of the "other" does not exclude someone from participating in the majority community. It creates a space for those existing in a diaspora to both maintain a connection to their roots while simultaneously becoming a part of their new environment. 


\section{Bibliography}

Baym, N. (2018). Music as Communication. In Playing to the Crowd: Musicians, Audiences, and the Intimate Work of Connection (pp. 31-53). New York: NYU Press. doi:10.2307/j.ctv12pnpcg. 5

Clarke, C. (2007, June 7). Our Town Could Be Your Life: Immigrants. Portland Mercury. https:// www.portlandmercury.com/music/our-town-could-be-your-life/Content?oid=339403.

Curry-Stevens, A. (2014) The Slavic Community in Multnomah County: An Unsettling Profile. Portland: Portland State University Coalition of Communities of Color. Retrieved May 20, 2021, from https://www.portlandoregon.gov/oehr/article/713232

Dundas, Z. (2000, April 26). From Russia with Shove. Willamette Weekly. http://wweek.com/ html/musicb051700.html.

Dushenko, K. (2005) Phrases from Russian literature. Moscow: Eksmo.

González, D. (2019). The construction of an Italian diasporic identity in the city of Buenos Aires at the turn of the 19th century. In Da Silva G. \& Hondros K. (Eds.), Music Practices Across Borders: (E)Valuating Space, Diversity and Exchange (pp. 167-190). Bielefeld: Transcript Verlag. Retrieved February 12, 2021, from http://www.jstor.org/stable/j.ctvnp0hzm.10

Portland, OR. Russian Gypsy Punk-Rock band Miru-Mir. (n.d.). http://www.barynya.com/ RussianMusic/gypsy_band_portland_oregon.htm.

Ramnarine, T. (2007). Musical Performance in the Diaspora: Introduction. Ethnomusicology Forum, 16(1), 1-17. Retrieved February 12, 2021, from http://www.jstor.org/stable/20184574

Rosemond, R. (2001, January). Rosebud. TwoLouies Magazine, 17. Retrieved May 20, 2021, from http://www.twolouiesmagazine.com/wp-content/uploads/2011/02/2L_1_2001.pdf

Song, Sarah. (2020) "Multiculturalism". The Stanford Encyclopedia of Philosophy. Edward N. Zalta (ed.). Retrieved May 18, 2021, from https://plato.stanford.edu/archives/fall2020/entries/ multiculturalism/.

Yang, H., Mikkonen, S., \& Winzenburg, J. (2020). Networking the Diaspora: MUSICAL ACTIVITIES OF THE RUSSIAN COMMUNITY. In Networking the Russian Diaspora: Russian 
Musicians and Musical Activities in Interwar Shanghai (pp. 34-61). Honolulu: University of Hawai'i Press. doi:10.2307/j.ctvn1td5w.8 
